\title{
Denning Ecology of Wolves in East-Central Alaska, 1993-2017
}

\author{
Kyle Joly, ${ }^{1,2}$ Mathew S. Sorum ${ }^{1}$ and Matthew D. Cameron ${ }^{1}$
}

(Received 4 May 2018; accepted in revised form 19 July 2018)

\begin{abstract}
Dens are a focal point in the life history and ecology of gray wolves (Canis lupus), and their location can influence access to key resources, productivity, survivorship, and vulnerability to hunting, trapping, and control efforts. We analyzed the selection of den sites and the phenology of their use inside the Yukon-Charley River National Preserve from 1993 to 2017 to enhance our understanding of this resource. At the landscape scale, we found that wolves in east-central Alaska selected den sites that were lower in elevation, snow free earlier in the spring, exposed to greater solar radiation, and closer to water. Den sites were also associated with areas that had burned less recently and had lower terrain ruggedness at the $1 \mathrm{~km}$ scale. These results supported our hypothesis that wolves would den relatively close to essential resources (water and prey) and in areas that are drier (melt earlier) in the spring. At the home range scale, wolves also selected den sites at lower elevations and showed a strong selection for the center of their home range. Furthermore, the average distance between active den sites was $37.3 \mathrm{~km}$, which is slightly greater than the average radius $(32.5 \mathrm{~km})$ of a home range of a pack. Our results support our hypothesis that dynamic social factors modulate the selection of environmental factors for den site location. Wolves den away from other packs to reduce competition and exposure to intraspecific conflict. High-quality denning habitat does not currently appear to be a limiting factor for this population. Females, on average, entered their dens on 10 May, stayed inside the den for eight days, and remained less than $1 \mathrm{~km}$ from the den for an additional six days after emerging. We found that wolves denning at higher elevations entered their dens later than those at lower elevations, which also supported one of our hypotheses. Lastly, we documented limited evidence of earlier denning over time. Long-term monitoring projects, such as ours, are critical in identifying these types of trends.
\end{abstract}

Key words: Canis lupus; den; habitat selection; natality; protected areas; pup rearing

RÉSUMÉ. Les tanières sont un point central du cycle biologique et de l'écologie du loup gris (Canis lupus). Leur emplacement peut influencer l'accès aux ressources principales, la productivité, la survie et la vulnérabilité à la chasse, au piégeage et aux mesures de contrôle. Afin de mieux comprendre cette ressource, nous avons analysé la sélection des emplacements de tanières et la phénologie de leur utilisation dans la réserve nationale Yukon-Charley Rivers pour les années allant de 1993 à 2017. À l'échelle du paysage, nous avons trouvé que les loups du centre-est de l'Alaska choisissaient des emplacements de tanières en moins grande altitude, plus près de l'eau, où la neige fondait plus vite au printemps et où le rayonnement solaire était plus grand. Par ailleurs, les emplacements des tanières étaient caractérisés par des secteurs brûlés moins récemment et un relief accidenté plus bas à l'échelle de $1 \mathrm{~km}$. Ces résultats ont permis d'appuyer notre hypothèse selon laquelle les loups établiraient leur tanière relativement près des ressources essentielles (eau et proies), dans des endroits plus secs (fonte hâtive) au printemps. À l'échelle du domaine vital, les loups choisissaient aussi des emplacements de tanières en plus faible altitude, avec une forte propension pour le centre de leur domaine. De plus, la distance moyenne entre les tanières actives était de $37,3 \mathrm{~km}$, ce qui est un peu plus grand que le rayon moyen $(32,5 \mathrm{~km})$ du domaine vital d'une meute. Nos résultats viennent appuyer notre hypothèse voulant que les facteurs sociodynamiques modulent la sélection de facteurs environnementaux pour l'emplacement des tanières. Les loups établissent leurs tanières à l'écart d'autres meutes afin de réduire la compétition et les possibilités de conflits intraspécifiques. En ce moment, la haute qualité de l'habitat pour l'établissement des tanières ne semble pas être un facteur limitant pour cette population. En moyenne, les femelles s'installaient dans leur tanière le 10 mai, y restaient pendant huit jours et demeuraient à moins d'un kilomètre de leur tanière pendant six autres jours après leur sortie. Nous avons remarqué que les loups optant pour des tanières en plus haute altitude s'y installaient plus tard que ceux en plus faible altitude, ce qui étayait aussi une de nos hypothèses. En dernier lieu, nous avons documenté les preuves restreintes d'établissement plus hâtif dans les tanières au fil des ans. Les projets de surveillance à long terme comme le nôtre jouent un rôle primordial dans la détermination de ces types de tendances.

Mots clés : Canis lupus; tanière; sélection de l'habitat; natalité; zones protégées; élevage des petits

Traduit pour la revue Arctic par Nicole Giguère.

\footnotetext{
${ }^{1}$ National Park Service, Yukon-Charley Rivers National Preserve and Central Alaska Inventory and Monitoring Network, 4175 Geist Road, Fairbanks, Alaska 99709, USA

${ }^{2}$ Corresponding author: kyle_joly@nps.gov

(C) United States Government. Administered by the Arctic Institute of North America
} 


\section{INTRODUCTION}

Large carnivores often are apex predators that serve important ecological functions in the environment. They can affect large herbivore populations directly, through predation (Gasaway et al., 1992; Sinclair et al., 2003; Ripple and Beschta, 2012; Joly et al., 2017), and also indirectly, by altering their behavior, movements, and habitat selection (Lima, 1998; Laundré et al., 2001; Fortin et al., 2005; Berger, 2007). These impacts, in turn, can cause cascading effects across different trophic levels (i.e., Paine, 1980; Carpenter et al., 1985; Beschta and Ripple, 2009; Prugh et al., 2009). Therefore, dramatic changes to large carnivore populations should be expected to cause far-ranging and consequential impacts to the natural environment.

Large carnivores have experienced massive population declines and range contractions globally (Ripple et al., 2014). Vast, remote, sparsely populated, and relatively intact ecosystems in Alaska have generally insulated these carnivores from pressures such as habitat loss and fragmentation, persecution by humans, depletion of their prey base, and the excessive hunting and trapping that are the ultimate causes of these losses. However, even in portions of Alaska, predator control efforts have substantively affected predator populations (i.e., Boertje et al., 1996; Keech et al., 2011). In east-central Alaska, predator control efforts outside the Yukon-Charley Rivers National Preserve affected the wolf (Canis lupus) population inside the preserve (Schmidt et al., 2017). The preserve was designated, in part, to maintain the environmental integrity of the region and to protect populations of wolves and other wildlife species and their habitat (Alaska National Interest Lands Conservation Act, 1980: Section 201 (10)). To accomplish this, wildlife managers need to understand the ecological requirements of the wolves relative to the overall take of wolves to aid in their conservation.

Dens can be critical for survival and are a limiting resource for some populations (McLoughlin et al., 2004; Ross et al., 2010; Klaczek et al., 2015). Dens provide shelter from inclement weather and protection from other predators. The relatively stable microclimate dens provide is critical for the survival of young (Laurenson, 1994; Fernández and Palomares, 2000; Benson et al., 2008). The location of the den site is important for several reasons. First, food resources for wolves during summer can be a limiting factor (Metz et al., 2012) and affect pup survival (Fuller, 1989; Benson et al., 2013; Klaczek et al., 2015). Most pup mortality occurs within the first six months after birth (van Ballenberghe and Mech, 1975; Benson et al., 2013). Since movements away from the den site are limited by the pups' motility for the first six weeks after birth (Fritts and Mech, 1981; Mills et al., 2008; Lake et al., 2013), locating the den close to an abundant food base is crucial (Ciucci and Mech, 1992; Klaczek et al., 2015). Second, dens are typically situated near fresh water (Ballard and Dau, 1983; Person and Russell, 2009; Benson et al., 2015; Jacobs and Ausband, 2018) so that the breeding female can drink while attending the pups (Mech, 1970). Third, the location of dens influences the vulnerability to predation of pups and adults alike (Benson et al., 2015; Jacobs and Ausband, 2018). For adult wolves, inter-pack strife accounts for a substantial number of mortalities (Murie, 1944; Mech et al., 1998; Smith et al., 2015; Schmidt et al., 2017). To mitigate these risks, wolves are thought to place their dens near the center of their territory (Fritts and Mech, 1981; Ciucci and Mech, 1992). While dens are not used year-round, in some respect they act as a center of activity for the pack's annual home range. Thus, den and territory location could affect the entire pack through activity, mortality, and recruitment (e.g., Borg et al., 2016).

The timing of parturition is physiologically linked to the timing of mating. The timing of these events is likely an adaptation to long-term climatic patterns and phenological cycles that allow for the optimal conditions to support young (Sandell, 1990; Bowyer et al., 1998; Walsh et al., 2016). Over the last few decades, winter snow in Alaska has been melting earlier in the spring, and vegetative green-up is also occurring earlier (Monahan et al., 2016; Cox et al., 2017). How such dramatic changes in the timing of seasons and related phenological cycles influence the denning ecology and demography of wolves is unknown.

The goal of our study was to elucidate the denning ecology of wolves in east-central Alaska. Our primary objectives were to identify landscape characteristics and societal factors associated with den site selection and to document phenological patterns of den use. Our first hypothesis was that wolves would select dens sites that have physical and environmental characteristics suitable for digging the den, thermoregulation, and rearing young. These characteristics would ensure that the den could be dug and would remain dry. Often these criteria mean that dens are located on knolls, eskers, and hillsides that are well drained, have no permafrost, and are composed of finegrained sediments (Ballard and Dau, 1983; Klaczek et al., 2015). These sediment types are associated with riparian zones at lower elevations. Our second hypothesis was that wolves would locate den sites near key resources, such as accessible fresh water (Mech, 1970; Ballard and Dau, 1983; Person and Russell, 2009; Benson et al., 2015) and prey (Ciucci and Mech, 1992; Klaczek et al., 2015). Our third hypothesis was that wolves centralize their den sites within their home range to avoid other packs. Wolves are territorial animals, so centralizing their den sites within their home ranges could reduce competition and inter-pack conflict (Fritts and Mech, 1981; Ciucci and Mech, 1992; Mladenoff et al., 1999). Our fourth hypothesis was that wolves would enter dens later at higher elevations, where snowmelt would occur later. Our final hypothesis was that over time, as the climate warmed, wolves would enter dens earlier.

\section{STUDY AREA}

The $23166 \mathrm{~km}^{2}$ study area encompassed the entire $10209 \mathrm{~km}^{2}$ of the Yukon-Charley Rivers National 


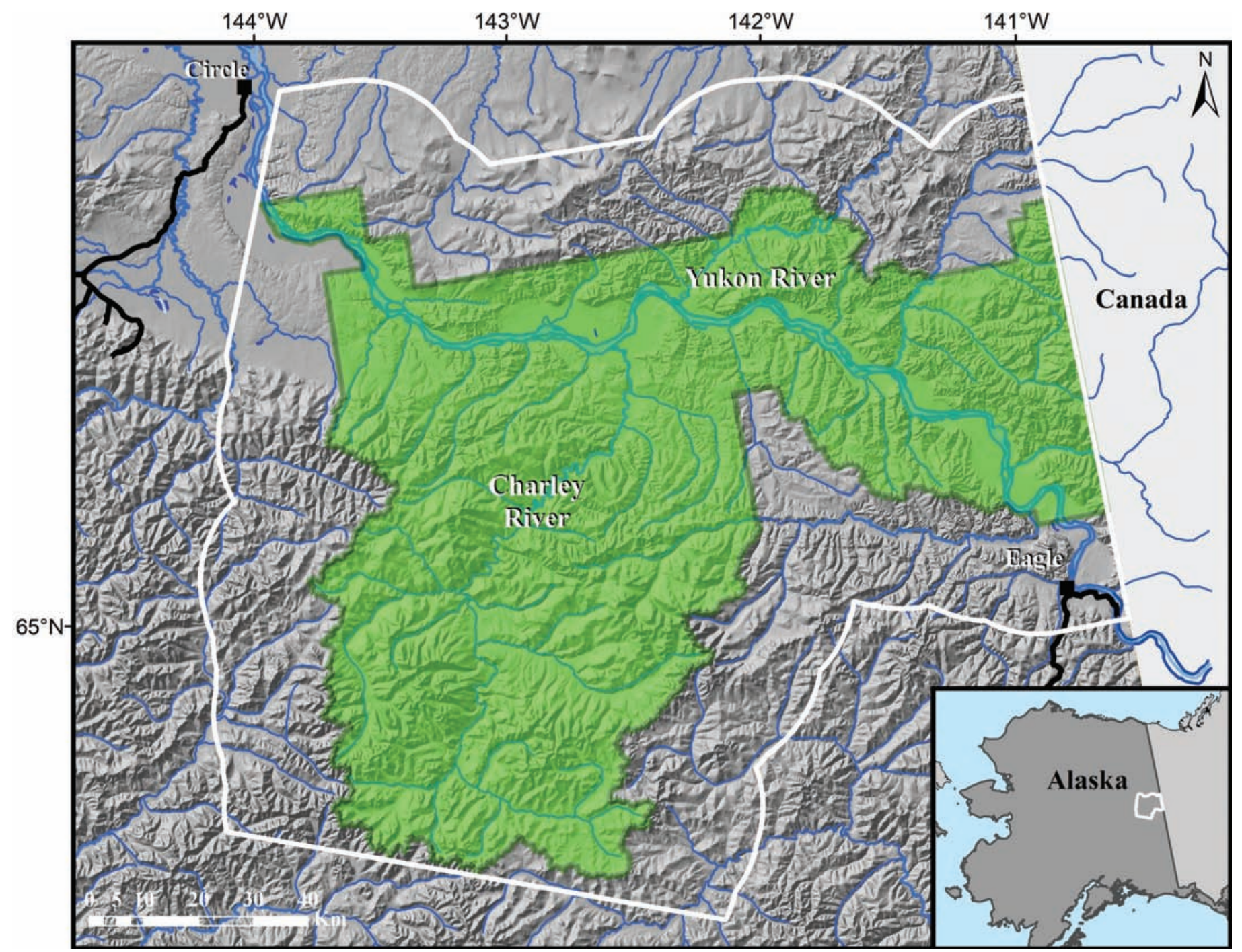

FIG. 1. Wolf den study area (outlined in white) in east-central Alaska, 1993-2017. The Yukon-Charley Rivers National Preserve is shown in green. Black squares indicate the villages of Circle (upper left) and Eagle (lower right). Black lines show roads.

Preserve and extended outwards a distance of $20 \mathrm{~km}$ from its perimeter (Fig. 1). We clipped the $20 \mathrm{~km}$ buffer at the international border with Canada and south of the preserve to match the extent of the habitat map (NPS, 1997) for the region. The region is quintessential boreal forest. Black spruce (Picea mariana) is the most common tree species, inhabiting areas with permafrost and poorly drained soils. Aspen (Populus tremuloides) and birch (Betula papyrifera) trees are common on south-facing slopes, whereas white spruce (Picea glauca) and poplars (Populus balsamifera) can be found in riparian corridors. Willow (Salix spp.), dwarf birch (Betula glandulosa), and alder (Alnus spp.) shrubs are often found lining the riparian corridors but also climbing the lower-elevation slopes. There are also extensive areas of wetland, tussock (e.g., Eriophorum spp.) tundra, and alpine tundra communities. Mountain peaks are generally lower than $2000 \mathrm{~m}$. The Yukon and Charley Rivers are the two main waterways (Fig. 1).

The full complement of native fauna exists within the study area, including low-density populations of moose
(Alces alces; Sorum and Joly, 2016) and Dall's sheep (Ovis dalli; Joly, 2015). Caribou (Rangifer tarandus) from the Fortymile caribou herd spend much of their time, including the calving period, in the study area (Boertje et al., 2017). During our 25-year study period (1993-2017), the herd ranged in size from 22000 to 71400 individuals (Boertje et al., 2017; Friedman, 2017). In addition to wolves, other predators include grizzly (Ursus arctos) and black (U. americanus) bears, wolverines (Gulo gulo), and red fox (Vulpes vulpes). King salmon (Oncorhynchus tshawytscha), northern pike (Esox lucius), and Arctic grayling (Thymallus arcticus) are common fish species.

The region has a typical continental climate with long (7-8 months), cold winters and short ( $2-3$ months) but warm, relatively dry summers. Snow typically begins to accumulate in October, reaching maximum depths of about $50 \mathrm{~cm}$ in March (Sousanes and Hill, 2014). Temperatures can drop to $-51^{\circ} \mathrm{C}$. Average annual temperature is about $-4^{\circ} \mathrm{C}$, with summer temperatures reaching a maximum of $33^{\circ} \mathrm{C}$ (Sousanes and Hill, 2014). During our 25-year study 
period, annual precipitation was approximately $31.5 \mathrm{~cm}$ (Sousanes and Hill, 2014). Warm, dry summers led to more than $40 \%$ of the preserve being burned by wildfire since the mid-1980s (Schmidt et al., 2017).

\section{METHODS}

\section{Identification and Characterization of Den Sites}

Wolves were found via aerial tracking and caught using darting techniques outlined by Schmidt et al. (2017). Most dens were located on radio-tracking flights, and their locations were recorded using GPS units on the aircraft. From 1993 to 2000, collars were equipped with VHF transmitters only. After 2000, both VHF and GPS collars were deployed. We calculated the Euclidean distance between active den sites for each year using ArcGIS. We assigned values for the following attributes to each den site: distance from waterway, elevation, aspect, slope, terrain ruggedness (Sappington et al., 2007) at the $180 \mathrm{~m}$ and $1 \mathrm{~km}$ scales, average day of year in spring that it becomes snow-free (Macander and Swingley, 2017), probability of permafrost (Pastick et al., 2015), time since last fire (Alaska Interagency Coordination Center, https://fire.ak.blm.gov/), solar radiation index (Keating et al., 2007), habitat type (NPS, 1997), and a forested:unforested ratio.

We lumped habitat types (30 altogether) into six categories (closed forest, open forest, tall shrub, low shrub, graminoids, and miscellaneous). To generate an index of cover around each den site, we calculated the ratio of forest to unforested habitat types by dividing the area of forested habitat within a $1 \mathrm{~km}$ radius of the den by the total area within the same radius.

\section{Selection of Den Sites at the Landscape Scale}

We investigated physiographic factors associated with den site selection at the landscape scale using resource selection functions (RSFs; Manly et al., 2002) to compare den locations used by wolves to other available sites across the study area. Over our 25-year study period, the wolves of east-central Alaska, as a population, have had the opportunity to den anywhere within a $20 \mathrm{~km}$ buffer zone around the preserve. Since our goal was to understand the static environmental attributes of den sites across our study area, regardless of history of use, den locations were used only once in this analysis. To define availability, we attributed 1000 random locations (available sites) with physiographic data that did not vary annually in the same manner as the den sites. When we clipped the buffer to fit the habitat map, 98 random locations were removed. We also removed two random locations that had implausible snow-free dates, leaving 900 available points within the study area.

We performed logistic regression using generalized linear models in R Version 3.4.3 (R Core Team, 2017), with den use as the response. We logit transformed the two covariates which were proportions, probability of permafrost and open/closed ratio (Warton and Hui, 2011), and standardized (subtracted the mean and divided by the standard deviation) the two measures of terrain ruggedness. We used 'miscellaneous' as our reference category for habitat comparisons. We tested for multi-collinearity of predictor variables using variance inflation factors with a cutoff value of 3 (Zuur et al., 2010), as well as a cutoff of higher than 0.5 for correlation values. Model selection was performed using Akaike's Information Criterion corrected for small sample sizes (AICc, Burnham and Anderson, 2002), starting with a global model of all covariates and testing biologically plausible subsets. In total, we tested 46 models (see online Appendix 1: Table S1). To assess the relative selection for each covariate, we reran the top model with standardized continuous covariates and interpreted coefficient values. We used the top-performing model to generate a predictive map for denning habitat. We evaluated the performance of our top model using leaveone-out cross-validation (Boyce et al., 2002), and measured the predictive capacity of our model with the area under the receiver operating curve (ROC) using the package "pROC" (Robin et al., 2011). ROC values from 0.7 to 0.8 indicate acceptable levels of discrimination for a model and above 0.8 indicates excellent discrimination (Hosmer et al., 2013).

\section{Selection of Den Sites at the Home Range Scale}

On an annual basis, the home range of one wolf pack is generally unavailable to another pack (Mladenoff et al., 1999). Therefore, we also investigated den site selection at the third order (use of a habitat component within a home range) of selection (Johnson, 1980) using RSFs to compare actual den locations to available sites within a breeding female's home range. We developed annual home ranges using only GPS data from breeding females to provide consistency. We delineated the annual home range, as determined by a $95 \%$ minimum convex polygon (MCP) to reduce the influence of extra-territorial forays, using the GPS data from the breeding female during the biological year prior to denning as available denning habitat. For example, we used GPS locations from 30 April 2003 to 1 May 2004 to create a home range from which random (available) points were compared to the 2004 den site of wolf No. 192. We used 1 GPS location per day and required a minimum of 300 locations in that year in order to develop an MCP. We generated and attributed 1000 random locations within the home range with the same environmental covariates as described for the landscape-scale analyses above. As an index of exposure to neighboring packs, we determined the distance from the den and random points to the edge of the annual home range. We then compared the random locations within the home range to the actual den site in a matched case-control framework. We limited our models to only two parameters because of the limited number of events (see Results) in 
this more restricted analysis (Hosmer et al., 2013), and thus did not include the six-level habitat variable. We performed conditional logistic regression using the 'clogit' function in the 'survival' package (Therneau, 2015) in R with the matched case-control sets as strata and pack identifier as the cluster to account for correlations between multiple years of denning for some packs.

\section{Denning Phenology}

We used the visual inspection-based estimates of denning onset outlined by Walsh et al. (2016) on our GPS data $(2001-17)$. The technique relies upon reduced daily movement rates and increased GPS location fix failures to determine when wolves begin to den. Using the same technique, we determined when wolves emerged from their dens (i.e., first GPS relocation after the period of failure to get a GPS fix) and how long they stayed there before moving more than $1 \mathrm{~km}$ from the site. This analysis led to the discovery of additional potential den sites (see Results). We used multiple linear regression to assess a set of candidate models to determine what variables were correlated with timing (day of year) of den entrance. We used size of the pack in spring, elevation, snow-free date, and year of the event as variables in the model, and model selection was based on AIC $c$. Latitude was strongly and negatively correlated with elevation, so it was not included as a variable. For duration spent in and at the den, we also included date of den entrance and estimated number of pups produced as variables.

\section{RESULTS}

\section{Identification and Characterization of Den Sites}

A total of 52 individual den site locations, from 26 different packs, were initially identified through direct aerial observations and cursory observations of the GPS collar data from 1993 to 2017. The average distance between active den sites was $37.3 \mathrm{~km}(\mathrm{SD}=15.1$; range 13.8-95.9). We identified active den sites in all years of the study, except 2014-16 when limited numbers of marked individuals reduced our ability to detect den sites. Consecutive use of individual den sites ranged from one to eight years, which led to 116 den-year records. On 10 occasions, a single pack used two different den sites in the same year: the 70 Mile Pack in 2011 and 2012, the Copper Mountain Pack in 2010, the Cottonwood Pack in 2003 and 2005, the Edwards Pack in 1996, the Flat Pack in 1995, and the Webber Creek Pack in 1999, 2000, and 2001.

\section{Selection of Den Sites at the Landscape Scale}

Means, standard deviations, and ranges of covariates used in the modeling process are displayed in Table 1 . We excluded the covariates of slope, aspect, and forested/ un-forested ratios since they had a variance inflation factor greater than 3 and were correlated with the solar radiation index and elevation. Correlation among all other variables was less than $50 \%$. The top two models for den site selection consisted of distance to water, elevation, time since last fire, average snow-free date, solar radiation index, terrain ruggedness at the $1 \mathrm{~km}$ scale, and probability of permafrost (online Appendix 1: Table S1). The second model, which differed from the top model only by the addition of probability of permafrost, was within two $\mathrm{AIC} c$ of the top model. Parameter estimates for these two models were nearly identical for shared covariates, and the confidence interval for probability of permafrost overlapped zero. Following the recommendations of Burnham and Anderson (2002) and Arnold (2010), we considered the addition of the permafrost covariate as uninformative. Our top model consisted of distance to water $(\beta=-0.0002$, $\mathrm{SE}=0.0001)$, elevation $(\beta=-0.0004, \mathrm{SE}=0.0002)$, scaled terrain ruggedness at $1 \mathrm{~km}$ resolution $(\beta=-0.3481$, $\mathrm{SE}=0.2011)$, snow-free date $(\beta=-0.0675, \mathrm{SE}=0.0256$, day $)$, time since last fire $(\beta=0.0169, \mathrm{SE}=0.0051$, year), and solar radiation index $(\beta=1.3665, \mathrm{SE}=0.6057)$. Of these, time since last fire exhibited the greatest relative selection, with wolves selecting older stands as den sites (Fig. 2). The negative relationship between snow-free date and denning was the second greatest relative selection, with wolves selecting sites that became snow free earlier in the spring. Overall, den sites were characterized by settings that were closer to water, lower in elevation, older in stand age, melted earlier in the spring, received more solar radiation, and exhibited less rugged terrain (Fig. 2). The 95\% CIs for elevation, solar radiation, and terrain ruggedness overlapped zero. We found no effect of habitat type on wolf denning at the resolution we considered. Figure 3 depicts relative probability of denning across the study area. Our top model had an ROC score of 0.77 , indicating acceptable discrimination.

\section{Selection of Den Sites at the Home Range Scale}

We developed 25 home ranges for breeding females from eight different packs, spanning 2004-15, for which we had a year of location data prior to denning and a corresponding actual den location. Annual home ranges averaged $2830 \mathrm{~km}^{2}$ (SE: $\pm 514 \mathrm{~km}^{2}$; range $743-11765 \mathrm{~km}^{2}$ ). Distance to home range edge $(\beta=0.0003$, robust $\mathrm{SE}=0.00006)$ and elevation $(\beta=-0.0066$, robust $\mathrm{SE}=0.0015)$ comprised the top performing model (online Appendix 1: Table S2). Wolves exhibited strong selection for areas near the center of their home range and lower elevations within their home range (Fig. 4).

\section{Denning Phenology}

From our GPS data of breeding females, we identified a total of 55 denning events, which occurred in all years from 2001 to 2017 except 2002 and 2016. Most (> 75\%) of the events matched known den sites; however, 13 did not 
TABLE 1. Parameters, with means, SD, and range, used to model selection of wolf denning habitat in east-central Alaska, $1993-2017$. Habitat type was also included as a categorical variable.

\begin{tabular}{|c|c|c|c|c|}
\hline Parameter & Definition & Mean & SD & Range \\
\hline \multicolumn{5}{|l|}{ A) Den sites: } \\
\hline $\begin{array}{l}\text { Dist }_{2} \mathrm{O} \\
\text { Elevation } \\
\text { ElevFromMean } \\
\text { Terrain } \\
\text { Snow } \\
\text { Fire } \\
\text { Solar } \\
\text { Permafrost }\end{array}$ & $\begin{array}{l}\text { Distance to water }(\mathrm{m}) \\
\text { Height above sea level }(\mathrm{m}) \\
\text { Absolute value height difference from landscape mean }(\mathrm{m}) \\
\text { Terrain Ruggedness Index at } 1 \mathrm{~km} \text { scale } \\
\text { Julian date when area became snow free } \\
\text { Number of years since the area last burned } \\
\text { Solar Radiation Index } \\
\text { Probability of the area being permafrost }\end{array}$ & $\begin{array}{l}1431 \\
575 \\
281 \\
0.07 \\
118 \\
83 \\
0.53 \\
0.70\end{array}$ & $\begin{array}{c}1378 \\
282 \\
161 \\
0.08 \\
7 \\
31 \\
0.27 \\
0.28\end{array}$ & $\begin{array}{c}39-5240 \\
207-1151 \\
4-530 \\
0.00-0.30 \\
104-136 \\
9-100 \\
-0.36-0.97 \\
0.00-0.97\end{array}$ \\
\hline \multicolumn{5}{|c|}{ B) Random locations } \\
\hline $\begin{array}{l}\text { Dist }_{2} \mathrm{O} \\
\text { Elevation } \\
\text { ElevFromMean } \\
\text { Terrain } \\
\text { Snow } \\
\text { Fire } \\
\text { Solar } \\
\text { Permafrost }\end{array}$ & $\begin{array}{l}\text { Distance to water }(\mathrm{m}) \\
\text { Height above sea level }(\mathrm{m}) \\
\text { Absolute value height difference from landscape mean }(\mathrm{m}) \\
\text { Terrain Ruggedness Index at } 1 \mathrm{~km} \text { scale } \\
\text { Julian date when area became snow free } \\
\text { Number of years since the area last burned } \\
\text { Solar Radiation Index } \\
\text { Probability of the area being permafrost }\end{array}$ & $\begin{array}{c}2259 \\
737 \\
278 \\
0.11 \\
124 \\
72 \\
0.34 \\
0.74\end{array}$ & $\begin{array}{c}1672 \\
331 \\
179 \\
0.09 \\
10 \\
36 \\
0.36 \\
0.21\end{array}$ & $\begin{array}{c}2-7991 \\
172-1708 \\
0-970 \\
0.00-0.43 \\
12-160 \\
1-100 \\
-0.59-0.99 \\
0.00-1.00\end{array}$ \\
\hline
\end{tabular}

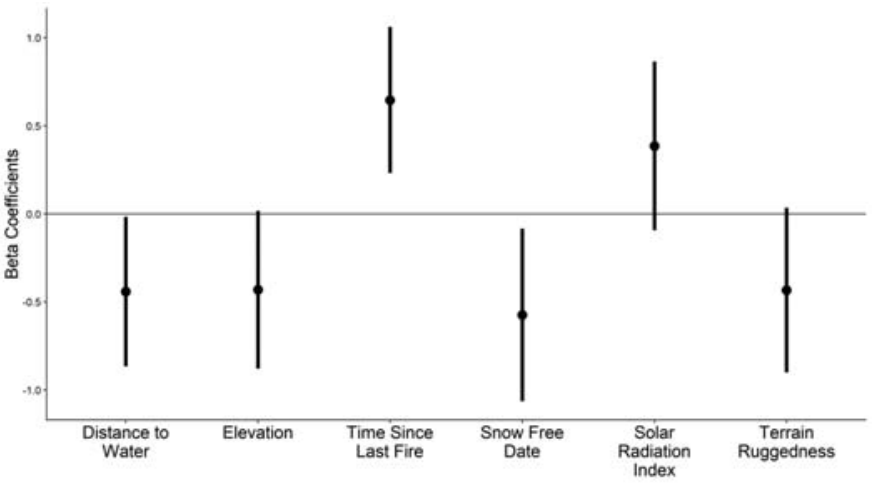

FIG. 2. Relative influence of six continuous covariates on modeling of wolf denning habitat in east-central Alaska, 1993-2017. Dots indicate the means and bars, the $95 \%$ confidence intervals. Covariates were standardized by subtracting the mean and dividing by the standard deviation.

and likely represent previously unknown den sites. In 2008 for the Step Mountain Pack and in 2012 and 2013 for the Snowy Peak Pack, more than one female per pack appeared to den (all other events were from 1 female/pack/year). Wolves entered their dens to give birth from 29 April to 30 May (day of year 119-150), with a mean date of 10 May (day of year 130; $\mathrm{SD}=6.5 ; \mathrm{n}=55$ events). Wolves stayed an average of 8.3 days $(\mathrm{SD}=3.7$; range $2-20)$ inside the den. After emerging from the den, wolves remained within $1 \mathrm{~km}$ of the den site for an additional 5.8 days $(\mathrm{SD}=7.7$; range $0-40)$. All 55 denning events showed the wolves returning to a single location: either the natal den site, a secondary den site (i.e., a den site to which the pups were moved after birth), or a rendezvous location.

The top model explaining the timing of entrance included elevation $(\beta=0.0039, \mathrm{SE}=0.0012)$ and year $(\beta=-0.3049, \mathrm{SE}=0.2272)$. The only other model within $2 \mathrm{AICc}(\triangle \mathrm{AIC} c=0.11)$ retained only elevation $(\beta=-0.0043, \mathrm{SE}=0.0011)$. For two denning events, we did not have spring pack size and since that variable was not in the top models, we re-ran our analyses without it. This only slightly modified our results as the top model was elevation $(\beta=0.0045, \mathrm{SE}=0.0012)$ alone and the only other model within $2 \mathrm{AIC} c(\triangle \mathrm{AIC} c=0.46)$ was composed of elevation $(\beta=0.0040, \mathrm{SE}=0.0012)$ and year $(\beta=-0.3695$, $\mathrm{SE}=0.2398)$. Elevation was significantly associated with denning onset $\left(\mathrm{R}^{2}=0.21, \mathrm{~F}=13.96, \mathrm{df}=54, p<0.01\right)$, with den entrance occurring later at higher elevation sites but earlier over time. Den entrances on 15 May or later have not occurred since 2011 (Fig. 5), when there were two (on 17 and 19 May). Of the den entrances occurring on 15 May or later, 85\% (11 of 13) occurred prior to 2009 (i.e., in $2001-08)$. This finding was not affected by any sampling bias as $49 \%$ of the den onsets were detected from 2001 to 2008 and $51 \%$ from 2009 to 2017 . We did not detect a significant correlation between duration of presence in or at the den with any of the variables we examined.

\section{DISCUSSION}

Den sites represent a critical component of wolf ecology, and understanding the process of selection for these features is important so that wildlife managers can make informed decisions regarding wolf management and conservation. Here, we investigated both physiographic and social factors associated with den site selection by wolves in interior Alaska. Our results suggest that wolves select lower-elevation river corridors that melt out earlier in the season, but also areas well away from the edges of their annual home ranges to reduce the risk of conspecific competition and conflict. This information is novel and informative for this region because den site selection can influence survival of adults and young (Laurenson, 1994; Fernández and Palomares, 2000; Benson et al., 2008, 2015; 


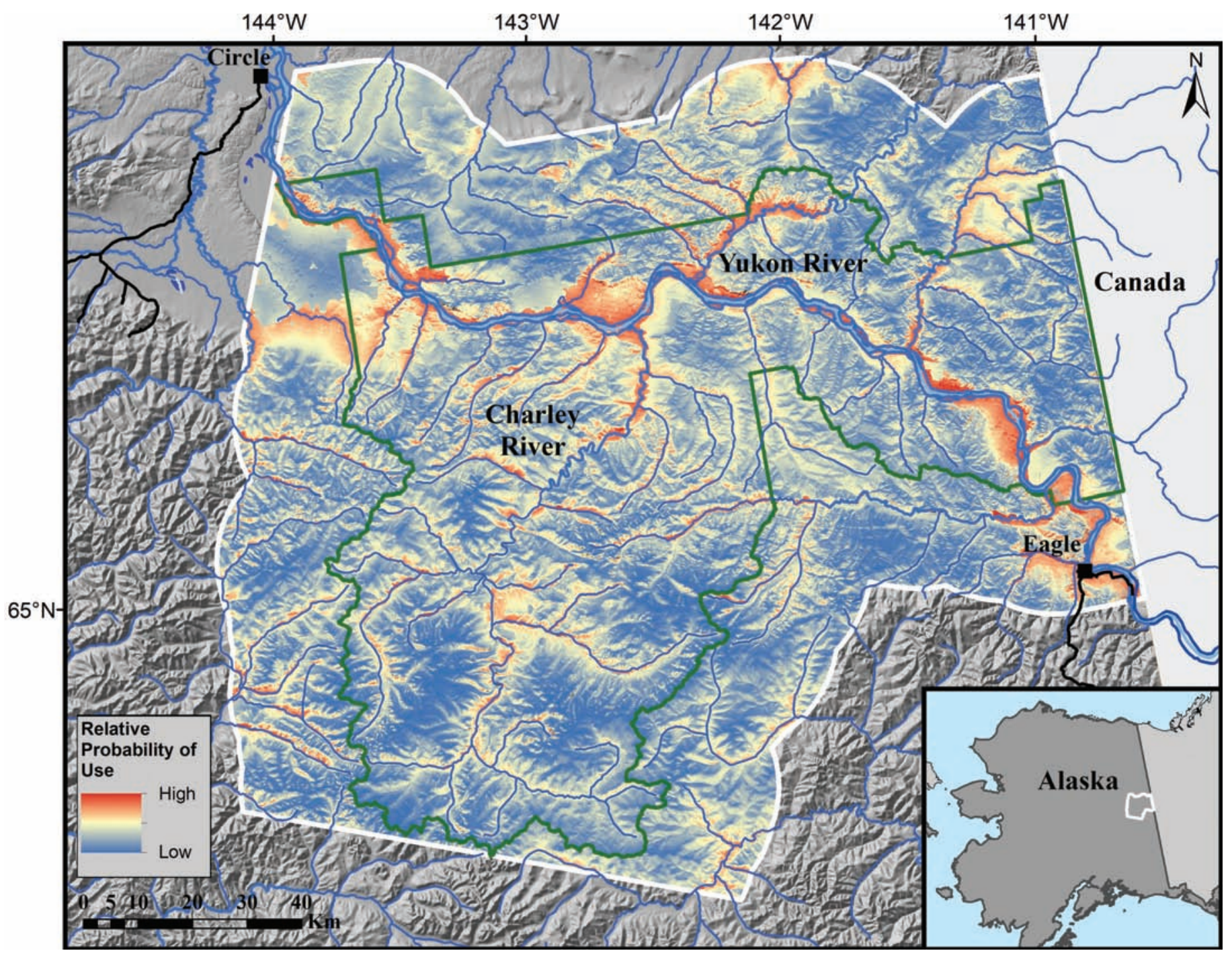

FIG. 3. Resource suitability map for wolf denning habitat in east-central Alaska, 1993-2017. Dark blue shades represent the lowest suitability (relative probability of selection), lighter shades represent greater suitability, and red shades, the greatest suitability.

Ross et al., 2010; Jacobs and Ausband, 2018). We expect our results will broadly inform management and conservation by documenting where and when wolves den, which could allow for data-driven decisions on appropriate hunting and trapping seasons and area closures.

Snow melts earlier at lower elevations, and we found that sites that became snow-free earlier were selected for denning at the landscape scale. These sites also had greater levels of solar radiation. Ballard and Dau (1983) found that dens were preferentially located on south- and east-facing slopes $(79 \%$ of the den sites we recorded were similarly facing), which is also related to higher levels of solar radiation. All of these conditions should promote warmth and dryness during the denning season. We suspect that presence of permafrost and type of soil (e.g., sand) are important factors in den site selection, but we did not have data at the necessary resolution to capture this relationship. Den sites were also located away from areas that had recently been burned by wildfires. Depending on edaphic conditions, old stands tend to be associated with forest habitat. Mature forests tend to be on well-drained soils in this region and could provide shade to aid thermoregulation of pups as summer arrives. However, as in other studies (e.g., Theuerkauf et al., 2003), differential selection by habitat type was not supported. Dens were also located in areas of lower terrain ruggedness at the $1 \mathrm{~km}$ scale. Lower ruggedness near the den site might increase sight lines for wolves (depending on vegetation), allowing for more time to retreat from or engage with other predators that might threaten their young. Thus, we feel our results support our hypothesis that den sites are selected for physical and environmental characteristics that are suitable for digging, thermoregulation, and rearing young.

At the landscape scale, we found that wolves selected den sites close to water and at lower elevations, which supports our hypothesis about resources and agrees with other studies. Having easy access to a reliable source of fresh water is critical for a breeding female attending her newborn pups (Mech, 1970; this study). Sites that are relatively lower in elevation tend to have greater access to 


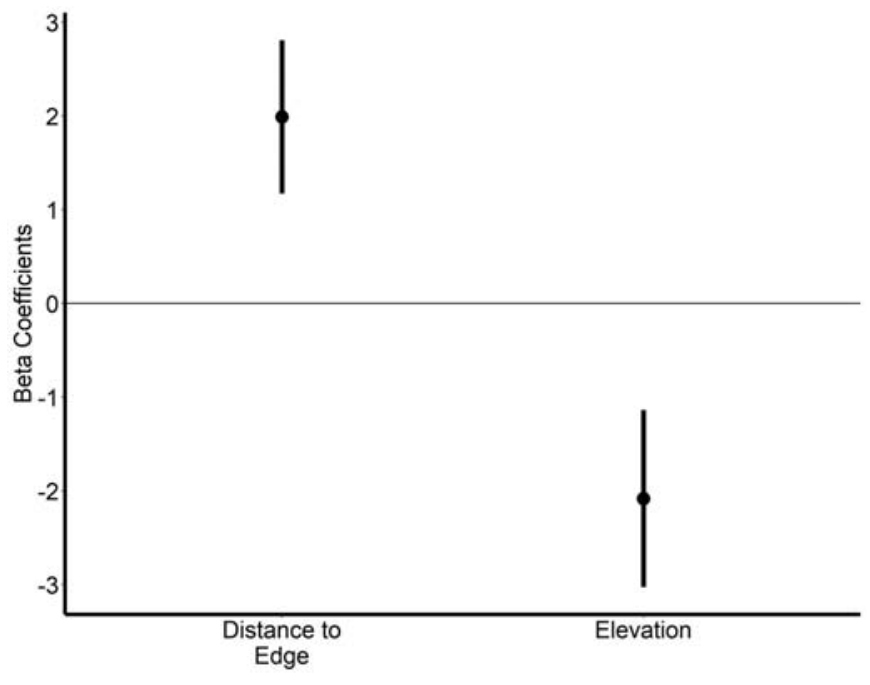

FIG. 4. Relative influence of standardized covariates on conditional logistic regression of den site selection based on annually varying home ranges of wolf packs in east-central Alaska, 2004-15. Dots indicate the means and bars, the $95 \%$ confidence intervals.

prey species such as moose (Sorum and Joly, 2016), beaver (Castor canadensis), snowshoe hares (Lepus americanus), fish, and waterfowl. Caribou are also commonly found at lower elevations during winter (Boertje et al., 2017). However, higher-elevation sites would have greater access to Fortymile Herd caribou calves that are born just after wolves emerge from their dens (Boertje et al., 2017). Thus, the connections between critical resources and selection of den sites still warrant additional fine-scale study; we recommend assessing wolf prey distribution, abundance, and availability as the next step.

High-quality denning habitat (Fig. 3) was relatively abundant across the landscape, and we do not believe it is a limiting factor for this population. Our landscape RSF map (Fig. 3) depicting relative probability of use for denning habitat is, we believe, the first of its kind in the region. Lower-elevation areas with greater solar radiation that melt out earlier in spring, and which were near waterways but away from recently burned areas, had the greatest relative probability of use. Two areas of high relative probability of use that did not have documented den sites stand out: the first is along the Yukon River downstream (northwest) of Eagle, and the second is upstream (southeast) of Circle. The first may lack documented den sites because it is relatively far away from our base of operations in the northwest portion of the preserve and may thus be affected by reduced sampling effort. Alternatively, the lack of den sites may be related to human use of the area. The Yukon River freezes solid in winter and people use it as a travel corridor. Increased hunting and trapping pressure and disturbance associated with proximity to the villages have the potential to influence den site selection. The lack of den sites upstream from Circle supports this latter line of reasoning, as the area is close to our base of operations. Additionally, other factors, both ecological (e.g., prey abundance, amount of terrain conducive to aerial capture operations) and

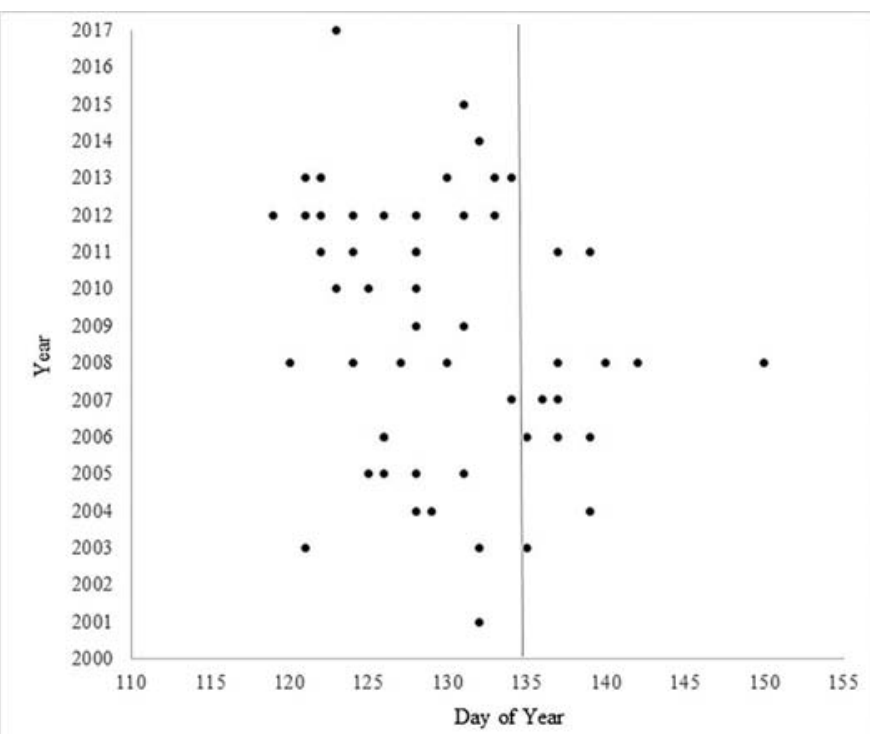

FIG. 5. Timing (day of year) when wolves entered dens in east-central Alaska, 2001-17. The vertical line indicates Day 135 (May 15) as a point of reference.

behavioral (e.g., social dynamics within or between packs), that we were not able to address at this scale may also be influencing where wolves select den sites and our ability to detect them. Our landscape analysis was limited to static physiographic aspects of den site selection, but a suite of biological and climatic factors that vary annually (e.g., wolf density, prey availability, and snow conditions) most likely also influence den site selection each year.

Our home range-based analysis suggests that the dynamic social structure of the wolf population in a given year modulates the selection of the physical landscape attributes for a denning location. As in the landscape scale analysis, we found that wolves selected for lower elevations relative to what was available within their home range. As noted above, use of lower elevations for denning is likely related to earlier snowmelt and improved access to key resources. Interestingly, we also found that wolves selected den sites near the center of their home ranges, as has been found in other studies (e.g., Trapp et al., 2008). This finding suggests that wolves attempt to reduce competition and conflict with other packs while optimizing access to prey. Centralizing den sites within home ranges and away from other packs reduces competition and inter-pack strife, which is a large contributor to wolf mortality (Murie, 1944; Mech et al., 1998; Smith et al., 2015; Schmidt et al., 2017). Having a den near the center of a pack's home range may thus benefit fitness (Fritts and Mech, 1981; Ciucci and Mech, 1992). We posit that a centralized den site may optimize access to prey in multiple directions, and thereby may improve hunting efficiency and reduce the vulnerability of wolves traveling alone during the summer, when pack cohesion is lower. Our findings agree with studies of other canids; for example, Moorcraft et al. (2006) found that coyote (Canis latrans) territories were influenced by prey availability as well as by avoidance of neighboring packs. 
Active den sites were located approximately $37.3 \mathrm{~km}$, on average, from the nearest active den site. The average home range size of packs in the region is $3322 \mathrm{~km}^{2}$ (Burch, 2013). A circle with this area has a radius of $32.5 \mathrm{~km}$. Therefore, we believe that these figures add further support to our hypothesis that wolves situate their dens centrally within their home range and away from other packs. For those populations for which den sites are well monitored, but radio collaring is limited, the use of distance to nearest active den has the potential to be an index of home range size, though more study of this relationship should be conducted. In the future, den site selection should be evaluated using annually varying factors, including distance to and overlap with the territories of other packs, prey abundance, level of human activity, and climatic variables, and alternative means to delineate home ranges (see Potts and Lewis, 2014; Kittle et al., 2015).

The onset of denning ranged from 29 April to 30 May, with a mean date of 10 May, which is remarkably similar to the dates reported elsewhere in Alaska (see Walsh et al., 2016). Denning in Alaska appears to occur a couple of weeks later than in Minnesota (second week of April; Fuller, 1989), but a couple of weeks earlier than in the Canadian Arctic (late May to early June; Heard and Williams, 1992), which suggests a strong nexus with latitude. Females stayed an average of eight days in the den and remained close $(<1 \mathrm{~km})$ to it for an additional six days. This is about 10 days less than Fuller (1989) reported for wolves in Minnesota. We suspect that much of this difference could be accounted for by differences in method, including the increased level of precision afforded by GPS technology that was not available in previous studies. Additional studies investigating whether the duration of females' stay at the den is related to available prey biomass are in order.

Onset of denning occurred later at higher-elevation sites, which may be related to delayed snowmelt or less available biomass of prey. 'Year' was also in the top models for timing of denning, with denning occurring earlier over time. The $95 \%$ CIs overlapped zero, so earlier onset of denning over time was not a strong relationship. However, since 2011, the onset of denning has always occurred prior to 15 May. We monitored onset of denning for 17 years $(2001-17)$ and found that $85 \%$ of the onset events that occurred on 15 May or later were during the first seven years of the study (i.e., in 2008 or before). Rapidly warming temperatures in the region have led to earlier snowmelt and vegetative green-up (Monahan et al., 2016; Cox et al., 2017). Here, we document evidence that these earlier events may in turn be affecting the timing of denning of wolves in east-central Alaska. Given the fixed gestation period of wolves, these factors may be indices of conditions wolves face during breeding (February and March) or conditions from the previous summer that in turn influence the timing of breeding and conception. We posit that the relationship between onset of denning and elevation suggests that wolves have the requisite plasticity to adapt to conditions at very fine temporal and spatial scales (i.e., within their home range), which may increase their resiliency to climate change. Further study of how changes in denning phenology affect the demography of wolves is warranted.

\section{ACKNOWLEDGEMENTS}

Funding for this project came from the National Park Service, Yukon-Charley Rivers National Preserve, and the Central Alaska Inventory and Monitoring Program. J. Burch led the wolfmonitoring program for the majority of its existence; without his efforts, this work would not have been possible. We thank all the pilots for decades of safe flying in difficult conditions and the scores of biologists that helped with project fieldwork over the years. A project of this duration would not be feasible without managers supportive of science and conservation; thus we thank G. Dudgeon, J. Rasic, M. MacCluskie, T. Liebscher, D. Mills, P. Rost, P. Knuckles, and others for keeping this project going. We thank J. Burch, M. MacCluskie, J. Rasic, J. Schmidt, and anonymous reviewers for providing comments on previous versions of this manuscript that greatly improved it. We thank L. Sanford and J. Eisaguirre for generously sharing their time and advice on statistical methods.

\section{APPENDIX 1}

The following tables are available in a supplementary file to the online version of this article at:

http://arctic.journalhosting.ucalgary.ca/arctic/index.php/ arctic/rp/suppFiles/4749/0

TABLE S1. Model results from all 46 generalized linear models for wolf den site locations, east-central Alaska, 1993-2017.

TABLE S2. Model results from 16 conditional logistic regression models for wolf den site locations, east-central Alaska, 2004-15.

\section{REFERENCES}

Alaska National Interest Lands Conservation Act. 1980. Public Law 96-487, 94 Stat. 2371.

https://www.nps.gov/locations/alaska/anilca.htm

Arnold, T.W. 2010. Uninformative parameters and model selection using Akaike's information criterion. Journal of Wildlife Management 74(6):1175-1178.

https://doi.org/10.2193/2009-367

Ballard, W.B., and Dau, J.R. 1983. Characteristics of gray wolf, Canis lupus, den and rendezvous sites in southcentral Alaska. Canadian Field-Naturalist 97:299-302.

Benson, J.F., Lotz, M.A., and Jansen, D. 2008. Natal den selection by Florida panthers. Journal of Wildlife Management 72(2):405-410.

https://doi.org/10.2193/2007-264 
Benson, J.F., Mills, K.J., Loveless, K.M., and Patterson, B.R. 2013. Genetic and environmental influences on pup mortality risk for wolves and coyotes within a Canis hybrid zone. Biological Conservation 166:133-141.

https://doi.org/10.1016/j.biocon.2013.06.018

Benson, J.F., Mills, K.J., and Patterson, B.R. 2015. Resource selection by wolves at dens and rendezvous sites in Algonquin Park, Canada. Biological Conservation 182:223-232. https://doi.org/10.1016/j.biocon.2014.12.010

Berger, J. 2007. Fear, human shields and the redistribution of prey and predators in protected areas. Biology Letters 3(6):620-623. https://doi.org/10.1098/rsbl.2007.0415

Beschta, R.L., and Ripple, W.J. 2009. Large predators and trophic cascades in terrestrial ecosystems of the western United States. Biological Conservation 142(11):2401-2414. https://doi.org/10.1016/j.biocon.2009.06.015

Boertje, R.D., Valkenburg, P., and McNay, M.E. 1996. Increases in moose, caribou, and wolves following wolf control in Alaska. Journal of Wildlife Management 60(3):474-489. https://doi.org/10.2307/3802065

Boertje, R.D., Gardner, C.L., Ellis, M.M., Bentzen, T.W., and Gross, J.A. 2017. Demography of an increasing caribou herd with restricted wolf control. Journal of Wildlife Management 81(3):429-448. https://doi.org/10.1002/jwmg.21209

Borg, B.L., Arthur, S.M., Bromen, N.A., Cassidy, K.A., McIntyre, R., Smith D.W., and Prugh, L.R. 2016. Implications of harvest on the boundaries of protected areas for large carnivore viewing opportunities. PLoS One 11(4): e0153808. https://doi.org/10.1371/journal.pone.0153808

Bowyer, R.T., van Ballenberghe, V., and Kie, J.G. 1998. Timing and synchrony of parturition in Alaskan moose: Long-term versus proximal effects of climate. Journal of Mammalogy 79(4):1332-1344. https://doi.org/10.2307/1383025

Boyce, M.S., Vernier, P.R., Nielsen, S.E., and Schmiegelow, F.K.A. 2002. Evaluating resource selection functions. Ecological Modelling 157(2-3):281-300. https://doi.org/10.1016/S0304-3800(02)00200-4

Burch, J. 2013. Annual report on vital signs monitoring of wolf (Canis lupus) distribution and abundance in Yukon-Charley Rivers National Preserve, Central Alaska Network: 2012 report. Natural Resource Technical Report NPS/CAKN/ NRTR-2012/736. Fort Collins, Colorado: National Park Service.

Burnham, K.P., and Anderson, D.R. 2002. Model selection and multimodel Inference: A practical information-theoretic approach, 2nd ed. New York: Springer-Verlag.

Carpenter, S.R., Kitchell, J.F., and Hodgson, J.R. 1985. Cascading trophic interactions and lake productivity: Fish predation and herbivory can regulate lake ecosystems. BioScience 35(10):634-639. https://doi.org/10.2307/1309989

Ciucci, P., and Mech, L.D. 1992. Selection of wolf dens in relation to winter territories in northeastern Minnesota. Journal of Mammalogy 73(4):899-905. https://doi.org/10.2307/1382214
Cox, C.J., Stone, R.S., Douglas, D.C., Stanitski, D.M., Divoky, G.J., Dutton, G.S., Sweeney, C., George, J.C., and Longenecker, D.U. 2017. Drivers and environmental responses to the changing annual snow cycle of northern Alaska. Bulletin of the American Meteorological Society 98(12):2559-2577.

https://doi.org/10.1175/BAMS-D-16-0201.1

Fernández, N., and Palomares, F. 2000. The selection of breeding dens by the endangered Iberian lynx (Lynx pardinus): Implications for its conservation. Biological Conservation 94(1):51-61. https://doi.org/10.1016/S0006-3207(99)00164-0

Fortin, D., Beyer, H.L., Boyce, M.S., Smith, D.W., Duchesne, T., and Mao, J.S. 2005. Wolves influence elk movements: Behavior shapes a trophic cascade in Yellowstone National Park. Ecology 86(5):1320-1330. https://doi.org/10.1890/04-0953

Friedman, S. 2017. Census puts Fortymile caribou herd population at more than 71,400, up from 51,000. Fairbanks Daily NewsMiner, November 10.

Fritts, S.H., and Mech, L.D. 1981. Dynamics, movements, and feeding ecology of a newly protected wolf population in northwestern Minnesota. Wildlife Monographs 80. 79 p.

Fuller, T.K. 1989. Population dynamics of wolves in north-central Minnesota. Wildlife Monographs 105. 41 p.

Gasaway, W.C., Boertje, R.D., Grangaard, D.V., Kelleyhouse, D.G., Stephenson, R.O., and Larsen, D.G. 1992. The role of predation in limiting moose at low densities in Alaska and Yukon and implications for conservation. Wildlife Monographs $120.59 \mathrm{p}$.

Heard, D.C., and Williams, T.M. 1992. Distribution of wolf dens on migratory caribou ranges in the Northwest Territories, Canada. Canadian Journal of Zoology 70(8):1504-1510. https://doi.org/10.1139/z92-207

Hosmer, D.W., Jr., Lemeshow, S., and Sturdivant, R.X. 2013. Applied logistic regression, 3rd ed. Hoboken, New Jersey: John Wiley and Sons, Inc.

Jacobs, C.E., and Ausband, D.E. 2018. Pup-rearing habitat use in a harvested carnivore. Journal of Wildlife Management 82(4):802-809.

https://doi.org/10.1002/jwmg.21434

Johnson, D.H. 1980. The comparison of usage and availability measurements for evaluating resource preference. Ecology 61(1):65-71. https://doi.org/10.2307/1937156

Joly, K. 2015. Aerial survey of Dall's sheep: Yukon-Charley Rivers National Preserve, July 2015. Natural Resource Report NPS/ YUCH/NRR - 2015/1020. Fort Collins, Colorado: National Park Service. $13 \mathrm{p}$.

Joly, K., Craig, T., Cameron, M.D., Gall, A.E., and Sorum, M.S. 2017. Lying in wait: Limiting factors on a low-density ungulate population and the latent traits that can facilitate escape from them. Acta Oecologica 85:174-183. https://doi.org/10.1016/j.actao.2017.11.004

Keating, K.A., Gogan, P.J.P., Vore, J.M., and Irby, L.R. 2007. A simple solar radiation index for wildlife habitat studies. Journal of Wildlife Management 71(4):1344-1348.

https://doi.org/10.2193/2006-359 
Keech, M.A., Lindberg, M.S., Boertje, R.D., Valkenburg, P., Taras, B.D., Boudreau, T.A., and Beckmen, K.B. 2011. Effects of predator treatments, individual traits, and environment on moose survival in Alaska. Journal of Wildlife Management 75(6): $1361-1380$. https://doi.org/10.1002/jwmg.188

Kittle, A.M., Anderson, M., Avgar, T., Baker, J.A., Brown, G.S., Hagens, J., Iwachewski, E., et al. 2015. Wolves adapt territory size, not pack size to local habitat quality. Journal of Animal Ecology 84(5):1177-1186. https://doi.org/10.1111/1365-2656.12366

Klaczek, M.R., Johnson, C.J., and Cluff, H.D. 2015. Den site selection of wolves (Canis lupus) in response to declining caribou (Rangifer tarandus groenlandicus) density in the central Canadian Arctic. Polar Biology 38(12):2007-2019. https://doi.org/10.1007/s00300-015-1759-z

Lake, B.C., Bertram, M.R., Guldager, N., Caikoski, J.R., and Stephenson, R.O. 2013. Wolf kill rates across winter in a low-density moose system in Alaska. Journal of Wildlife Management 77(8):1512-1522.

Laundré, J.W., Hernández, L., and Altendorf, K.B. 2001. Wolves, elk, and bison: Reestablishing the "landscape of fear" in Yellowstone National Park, U.S.A. Canadian Journal of Zoology 79(8):1401-1409. https://doi.org/10.1139/z01-094

Laurenson, M.K. 1994. High juvenile mortality in cheetahs (Acinonyx jubatus) and its consequences for maternal care. Journal of Zoology (London) 234(3):387-408. https://doi.org/10.1111/j.1469-7998.1994.tb04855.x

Lima, S.L. 1998. Nonlethal effects in the ecology of predator-prey interactions: What are the ecological effects of anti-predator decision-making? Bioscience 48(1):25-34.

Macander, M.J., and Swingley, C.S. 2017. Landsat snow persistence and snow regime mapping for Alaska, and lichen cover mapping for Yukon-Charley Rivers National Preserve. Final Report. Fairbanks, Alaska: ABR, Inc.

Manly, B.F.J., McDonald, L.L., Thomas, D.L., McDonald, T.L., and Erickson, W.P. 2002. Resource selection by animals: Statistical design and analysis for field studies, 2nd ed. Dordrecht: Kluwer Academic Publishers. 221 p.

McLoughlin, P.D., Walton, L.R., Cluff, H.D., Paquet, P.C., and Ramsay, M.A. 2004. Hierarchical habitat selection by tundra wolves. Journal of Mammalogy 85(3):576-580. https://doi.org/10.1644/BJK-119

Mech, L.D. 1970. The wolf: The ecology and behavior of an endangered species. Minneapolis: University of Minnesota Press. 384 p.

Mech, L.D., Adams, L.G., Meier, T.J., Burch, J.W., and Dale, B.W. 1998. The wolves of Denali. Minneapolis: University of Minnesota Press. 227 p.

Metz, M.C., Smith, D.W., Vucetich, J.A., Stahler, D.R., and Peterson, R.O. 2012. Seasonal patterns of predation for gray wolves in the multi-prey system of Yellowstone National Park. Journal of Animal Ecology 81(3):553 - 563. https://doi.org/10.1111/j.1365-2656.2011.01945.x
Mills, K.J., Patterson, B.R., and Murray, D.L. 2008. Direct estimation of early survival and movements in eastern wolf pups. Journal of Wildlife Management 72(4):949-954. https://doi.org/10.2193/2006-457

Mladenoff, D.J., Sickley, T.A., and Wydeven, A.P. 1999. Predicting gray wolf landscape recolonization: Logistic regression models vs. new field data. Ecological Applications 9(1):37-44. https://doi.org/10.1890/1051-0761(1999)009[0037:PGWLRL]2. $0 . \mathrm{CO} ; 2$

Monahan, W.B., Rosemartin, A., Gerst, K.L., Fisichelli, N.A., Ault, T., Schwartz, M.D., Gross, J.E., and Weltzin, J. F. 2016. Climate change is advancing spring onset across the U.S. national park system. Ecosphere 7(10): e01465.

https://doi.org/10.1002/ecs2.1465

Moorcroft, P.R., Lewis, M.A., and Crabtree, R.L. 2006. Mechanistic home range models capture spatial patterns and dynamics of coyote territories in Yellowstone. Proceedings of the Royal Society B: Biological Sciences 273(1594):1651 - 1659. https://doi.org/10.1098/rspb.2005.3439

Murie, A. 1944. The wolves of Mount McKinley. Fauna of the National Parks Series Number 5. Washington, D.C.: U.S. Government Printing Office.

NPS (National Park Service). 1997. Land cover map of YukonCharley Rivers National Preserve. Anchorage, Alaska: NPS.

Paine, R.T. 1980. Food webs: Linkage, interaction strength and community infrastructure. Journal of Animal Ecology 49(3):667-685.

https://doi.org/10.2307/4220

Pastick, N.J., Jorgenson, M.T., Wylie, B.K., Nield, S.J., Johnson, K.D., and Finley, A.O. 2015. Distribution of near-surface permafrost in Alaska: Estimates of present and future conditions. Remote Sensing of Environment 168:301 - 315 . https://doi.org/10.1016/j.rse.2015.07.019

Person, D.K., and Russell, A.L. 2009. Reproduction and den site selection by wolves in a disturbed landscape. Northwest Science 83(3):211-224.

https://doi.org/10.3955/046.083.0305

Potts, J.R., and Lewis, M.A. 2014. How do animal territories form and change? Lessons from 20 years of mechanistic modelling. Proceedings of the Royal Society B: Biological Sciences 281(1784): 20140231.

https://doi.org/10.1098/rspb.2014.0231

Prugh, L.R., Stoner, C.J., Epps, C.W., Bean, W.T., Ripple, W.J., Laliberte, A.S., and Brashares, J.S. 2009. The rise of the mesopredator. BioScience 59(9):779-791.

https://doi.org/10.1525/bio.2009.59.9.9

R Core Team. 2017. R: A language and environment for statistical computing. Vienna, Austria: R Foundation for Statistical Computing. https://www.R-project.org/

Ripple, W.J., and Beschta, R.L. 2012. Large predators limit herbivore densities in northern forest ecosystems. European Journal of Wildlife Research 58(4):733-742.

Ripple, W.J., Estes, J.A., Beschta, R.L., Wilmers, C.C., Ritchie, E.G., Hebblewhite, M., et al. 2014. Status and ecological effects of the world's largest carnivores. Science 343(6167): 1241484. https://doi.org/10.1126/science.1241484 
Robin, X., Turck, N., Hainard, A., Tiberti, N., Lisacek, F., Sanchez, J.-C., and Müller, M. 2011. pROC: An open-source package for $\mathrm{R}$ and $\mathrm{S}+$ to analyze and compare ROC curves. BMC Bioinformatics 12: 77. https://doi.org/10.1186/1471-2105-12-77

Ross, S., Kamnitzer, R., Munkhtsog, B., and Harris, S. 2010. Densite selection is critical for Pallas's cats (Otocolobus manul). Canadian Journal of Zoology 88(9):905-913. https://doi.org/10.1139/Z10-056

Sandell, M. 1990. The evolution of seasonal delayed implantation. Quarterly Review of Biology 65(1):23-42.

Sappington, J.M., Longshore, K.M., and Thompson, D.B. 2007. Quantifying landscape ruggedness for animal habitat analysis: A case study using bighorn sheep in the Mojave Desert. Journal of Wildlife Management 71(5):1419-1426. https://doi.org/10.2193/2005-723

Schmidt, J.H., Burch, J.W., and MacCluskie, M.C. 2017. Effects of control on the dynamics of an adjacent protected wolf population in interior Alaska. Wildlife Monographs 198(1). $30 \mathrm{p}$. https://doi.org/10.1002/wmon.1026

Sinclair, A.R.E., Mduma, S., and Brashares, J.S. 2003. Patterns of predation in a diverse predator-prey system. Nature 425:288-290.

Smith, D.W., Metz, M.C., Cassidy, K.A., Stahler, E.E., Mcintyre, R.T., Almberg, E.S., and Stahler, D.R. 2015. Infanticide in wolves: Seasonality of mortalities and attacks at dens support evolution of territoriality. Journal of Mammalogy 96(6):1174-1183.

https://doi.org/10.1093/jmammal/gyv125
Sorum, M.S., and Joly, K. 2016. Moose (Alces alces) population survey in Yukon-Charley Rivers National Preserve, November 2015. Natural Resource Report NPS/YUCH/NRR—2016/1150. Fort Collins, Colorado: National Park Service. 15 p.

Sousanes, P.J., and Hill, K.R. 2014. Annual climate summary 2012: Central Alaska Network. Natural Resource Data Series NPS/CAKN/NRDS-2014/606. Fort Collins, Colorado: National Park Service.

Therneau, T. 2015. A package for survival analysis in S, version 2.38 .

https://CRAN.R-project.org/package=survival

Theuerkauf, J., Rouys, S., and Jedrzejewski, W. 2003. Selection of den, rendezvous, and resting sites by wolves in the Bialowieza Forest, Poland. Canadian Journal of Zoology 81(1):163 - 167. https://doi.org/10.1139/Z02-190

Trapp, J.R., Beier, P., Mack, C., Parsons, D.R., and Paquet, P.C. 2008. Wolf, Canis lupus, den site selection in the Rocky Mountains. Canadian Field-Naturalist 122(1):49-56.

Van Ballenberghe, V., and Mech, L.D. 1975. Weights, growth, and survival of timber wolf pups in Minnesota. Journal of Mammalogy 56(1):44-63.

Walsh, P.B., Sethi, S.A., Lake, B.C., Mangipane, B.A., Neilson, R., and Lowe, S. 2016. Estimating denning date of wolves with daily movement and GPS location fix failure. Wildlife Society Bulletin 40(4):663-668. https://doi.org/10.1002/wsb.703

Warton, D.I., and Hui, F.K.C. 2011. The arcsine is asinine: The analysis of proportions in ecology. Ecology 92(1):3-10.

Zuur, A.F., Ieno, E.N., and Elphick, C.S. 2010. A protocol for data exploration to avoid common statistical problems. Methods in Ecology and Evolution 1(1):3-14. https://doi.org/10.1111/j.2041-210X.2009.00001.X 